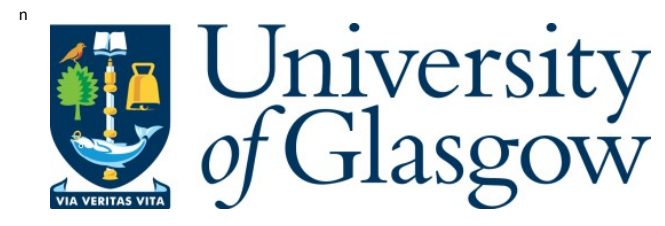

Holland, J., and Solomon, T. (2014) Affect is what states make of it: articulating everyday experiences of 9/11. Critical Studies on Security, 2 (3). pp. 262-267. ISSN 2162-4887

Copyright @ 2014 Taylor \& Francis

A copy can be downloaded for personal non-commercial research or study, without prior permission or charge

Content must not be changed in any way or reproduced in any format or medium without the formal permission of the copyright holder(s)

http://eprints.gla.ac.uk/94331/

Deposited on: 19 December 2014

Enlighten - Research publications by members of the University of Glasgow http://eprints.gla.ac.uk 


\section{Affect is What States Make of it: Articulating Everyday Experiences of 9/11}

Jack Holland (corresponding author)

School of Politics, University of Surrey, Guildford, Surrey, GU2 7XH

01483683169

j.holland@surrey.ac.uk

\section{Ty Solomon}

School of Social and Political Sciences, University of Glasgow, Glasgow, G12 8RT 01413308406

ty.solomon@glasgow.ac.uk

Jack Holland is Lecturer in International Relations at the University of Surrey. He is author of Selling the War on Terror: Foreign Policy Discourses after 9/11 (Routledge 2013), co-author of Security: A Critical Introduction (Palgrave 2014), and co-editor of Obama's Foreign Policy: Ending the War on Terror (Routledge 2013). He has published on US, UK and Australian foreign policy in journals such as: European Journal of International Relations, International Political Sociology, British Journal of Politics and International Relations, and Millennium Journal of International Studies.

Ty Solomon is Lecturer in International Relations at the University of Glasgow. His research interests include the overlapping influences of language, emotions, and identity in foreign policy, the politics of neoconservatism in American foreign policy, and time/temporality in politics. He has published and has forthcoming work in journals such as International Studies Quarterly, European Journal of International Relations, Review of International Studies, Cooperation and Conflict, Millennium, and New Political Science. 


\begin{abstract}
This article considers the politics of affect and official discourses of ' $9 / 11$ '. Drawing on the work of William Connolly and others, it is argued that to understand the resonance of dominant constructions of ' $9 / 11^{\prime}$ ' it is necessary to revisit their successful incorporation of prevalent American affective experiences of September $11^{\text {th }}$. To date, this relationship between affect, resonance, and discourse has been underexplored in International Relations. Its investigation offers important empirical insights on resonance, as well as theoretical innovation in connecting established work on narrative and discourse with emerging work on bioculture and affect. To this end, the article introduces a framework for the future analysis of affect, culture and discourse within International Relations. The article concludes, however, that, notwithstanding its importance to resonance, in 'crisis' situations such as '9/11', affect is what states make of it.
\end{abstract}

Keywords: affect, emotion, culture, discourse, 9/11

Word count: 8143 


\section{Affect is What States Make of it:}

\section{Articulating Everyday Experiences of 9/11}

\section{Introduction}

This article considers the affective politics of ' $9 / 11$ ', by mobilising the theoretical constructs of culture, affect and discourse. The article reflects on the relationship between cultural context, affective experience and discursive construction - a key relationship that remains underdeveloped in IR. This relationship has substantial theoretical and empirical implications for what have become two of the field's most employed concepts - identity and discourse. The concept of discourse is key to understanding the social constructed-ness of foreign policy and is also a crucial link in the complex relationship between affect and emotion. Moreover, this relationship holds normative implications for understanding and contesting the logic of the 'War on Terror'. Drawing on the work of William Connolly and others, we see that the political possibility of foreign policy is partially determined in the relationship between affective experience and discursive construction. In short, the article argues that the political possibility of foreign policy is partially determined by the role of affective investment, which is presently underexplored in International Relations, despite its centrality to issues of resonance and discursive dominance. 
The article is structured in three sections. First, the article defines the key terms used and theorises the ways in which culture, affect and discourse relate. We outline the importance of affect, the interpenetration of biology and culture, and the centrality of building on everyday experience in the crafting of resonant discourse. Second, after a discussion of the key concepts, the affective, cultural and discursive elements of the American response to '9/11' are outlined in turn. Within the latter, the bioculturally embedded production of the official American construction of ' $9 / 11^{\prime}$ is traced through four empirical examples of how the official "War on Terror" discourse resonated with and in many ways helped to account for American audiences' affective experiences of the 9/11 attacks. Third, we bring our theoretical and empirical contributions together in order to deliver the argument that, while affect matters and must be taken seriously, the state retains a significant ability to articulate affect as emotion in the construction of resonant discourses.

Our argument hinges on this process of naming affect as emotion. We argue that the political possibility of foreign policy is partially determined through the affective investment of the national audience within it. Affect, then, is certainly key and often overlooked: it shapes foreign policy discourses and popular responses to events, as well as sustaining them at a visceral level. Often, however, and especially in moments of crisis such as $9 / 11$, the state retains an ability to articulate affect as emotion - affect is what states make of it - and this is key to enabling a particular foreign policy response. This article therefore makes a contribution to literatures attempting to understand the reaction to 9/11, through the development of a framework for conceptualising the 
relationship of affect, emotion and discourse, as well as by highlighting the role (and power) of the state in this relationship.

\section{Building on Experience: Affect, Biology, Culture, Discourse, Emotion (ABCDE)}

The Bush administration did not write ' $9 / 11$ ' and the 'War on Terror' on a social blank slate, but rather actively and persuasively plugged into the affective, emotional and cultural landscape carved out by the events of September $11^{\text {th. It }}$ has become commonplace in works discussing 'culture' to lament that this is one of the most complex words in the English language (Williams 1983). To compound matters, affect and emotion are not particularly straightforward either. In recent years there has been a growing interest in the roles of affect and emotion in world politics (Crawford, 2000; Bleiker and Hutchison, 2008; Mercer, 2010; Ross, 2006). ${ }^{1}$ Some of these scholars draw a distinction between affect and emotion, arguing that they are best understood as separate yet related concepts. For example, Sasley (2010: 689) conceptualizes affect as “one aspect of emotions" which refers to general valences of positive or negative feelings towards an object and thus often functions as a heuristic for decision making. Similarly, Ross distinguishes between more “coherent 'feelings' such as vengeance or anger" and "affective energies" that are more nebulous yet often no less politically consequential (Ross, 2006: 212). Hutchison (2010: 84) contends that "affect is different from an emotion in that an emotion is an intense feeling that characterises one's state of mind" whereas affect is "an inner disposition or

\footnotetext{
${ }^{1}$ See also the recent forum on emotions and security in Critical Studies on Security 2013, 1(1).
} 
feeling" or "mood". While these conceptualizations are helpful, they nevertheless downplay the tricky relationship of affect and emotion to political discourse. It is important to think more specifically about the entangling linkages between all three phenomena. In this task, Shouse is helpful:

'Although... routinely used interchangeably, it is important not to confuse affect with emotions ... Feelings are personal and biographical, emotions are social, and affects are prepersonal' (Shouse, 2005; see also Massumi 2007).

Solomon draws upon Lacanian theory to conceptualise the relationship between affect, emotion and discourse, and helps to clarify the affect-emotion distinction further:

'...emotions result when extra-discursive affect is translated into recognizable emotional signifiers within discourse. Affect is understood here as amorphous potential that remains outside of discourse, which is difficult to articulate but nevertheless has effects within discourse. Emotion, on the other hand, can be viewed as the "feeling" that signifiers "represent" once names are attached to affect, thereby conferring on them discursive reality' (Solomon, 2012: 908).

Affect, then, is seen to be somehow beyond and before discourse. Although a form of 'feeling', affect occurs prior to the thinking of and about 'feeling'; despite being neurological, affect is a largely non-conscious process as opposed to consciously-registered cognitive feelings. Feeling entails a degree of self-analysis and contemplation that affect does not. Affect is often more associated with bodily (biological) senses and pre-conscious reactions that occur just prior to cognitive awareness. Drawing together these insights, then, affect is the initial 
component and mediation of experience by the body and the brain. Emotion is that symbolic intersubjective process of categorising the apparent 'feelings' that later reflection upon affect names. Discourse is, of course, one such way in which intersubjective notions are shared and mutually agreed upon. Emotions such as 'sadness' and 'anger', for example, were central to the discursive construction of ' $9 / 11$ ' by the Bush Administration and the wider culture (Jackson, 2005). They helped to name affective experiences of September $11^{\text {th }}$ which were initially more frequently categorised around more nebulous notions such as 'lack' and 'shock', as discussed below. While this is a complex relationship, it can be helpfully thought of as "ABCDE". Affect is a Biological response to an event, which is conditioned by Culture, and later named within Discourse as Emotion. Affect, therefore, is that experience of an event, which is biological, cultural and somehow before and beyond its discursive articulation.

The complex linkages between these factors have largely gone underexplored in IR. While there is much work that has drawn upon and conceptually elaborated the concepts of culture and discourse, and a growing literature analysing the politics of affects and emotions, it is theoretically fruitful to examine how these factors permeate each other and thus more comprehensively understand how they reinforce each other in constituting collective understandings and in producing political outcomes. Culture, for example, is defined in one prominent IR text as "the context within which people give meanings to their actions and experiences and make sense of their lives" (Weldes et al., 1999: 1). Another defines it as "a set of evaluative standards, such as norms or values" and “cognitive standards" such as social rules (Jepperson et al., 1996: 56). While 
useful in pointing attention towards social and ideational factors (beyond strictly materialist and rationalist factors), most of these approaches to culture in IR tend to downplay the affective aspects that sustain many dimensions of culture, and are often not synonymous with the more cognitive elements that these definitions emphasize (see Lapid and Kratochwil, 1995; Lebow, 2009).

Similarly, as many in IR have detailed, discourse is often defined as "framings of meaning and lenses of interpretation, rather than objective, historical truths" (Hansen, 2006: 7), or as "structures of signification which construct social realities" rather than being naturally given (Milliken, 1999: 229). Language is viewed as "a system of differential signs, and meaning is not established by the essence of a thing itself but through a series of juxtapositions, where one element is valued over its opposite" (Hansen, 2006: 19). While much of this work rightly focuses on exposing the contingency of political discourses and aims to demonstrate the relational construction of meaning through the differential juxtaposition of signifiers, it also tends to neglect precisely how discourses affectively resonate among receiving audiences. Moreover, it implicitly tends to equate meaning with linguistic and symbolic systems, rather than unpacking the pre-discursive affective responses which often give rise to signifiers and discourses which attempt to name - and attach meaning to - such affective responses (see Campbell, 1998; Doty, 1993; Hansen, 2011).

This is also what the above framework adds to current understandings of affect in IR. If, as some IR scholars argue, a useful distinction is made between affect and emotion, their relationship still remains unclear in many of these accounts. 
Importantly, extant work has also largely yet to analyze how affect potentially transforms into emotion. This is key because, as Ross argues, "investigating these [affective] processes differs from existing research on emotional dimensions of identity by relaxing the expectation that such emotions involve reflection and meaning" (Ross, 2006: 210; Ross 2014). Additionally, investigating the potential transformation of affect into emotion via discourse takes us closer to understanding the frameworks of discursive and symbolic power that many in IR have emphasized (see Williams, 2007). The empirical payoff here holds considerable promise. Conceptualizing these links between biological affect, culture, discourse, and emotion contributes a crucial yet neglected factor in the literature that explains the US war on terror policies by recourse to its discursive construction. As illustrated below, discourse approaches in IR and FPA should more thoroughly account for the ways in which affective reactions are intimately linked to discourse and how the naming of emotions often results from this entanglement, thus producing resonant and often hegemonic discourses.

Two points require further elaboration. First, we do not wish to imply that this is a simple, linear process suggesting (Humean) causation. Rather, our framework represents a deliberately parsimonious attempt to conceptualise these interwoven elements in order to redress persistent oversights and conflations. Second, and relatedly, our understanding of resonance draws on two literatures. Resonance is certainly achieved through appeal and acceptance by an audience (e.g. Balzacq 2005; Barnett 1999, Holland 2013); and it involves the infiltration and amplification of discourses as they 'dissolve into each other' (Connolly 2005: 870). Building on Connolly, we suggest that resonance can be achieved through 
the blending and dissolution of textual and non-textual (i.e. affective) elements, such that they form 'qualitative assemblages': 'complexities of mutual imbrication and interinvolvement' (ibid.). As Protevi (2010: 1, our emphasis) notes, it is important to acknowledge the 'assemblage as the imbrication of the social and the somatic'. Affective investment, we argue, is an important and sometimes overlooked process through which these assemblages are formed and resonance achieved.

\section{Affect, Culture, Discourse and 9/11}

\section{Experiencing September 11th: Biocultural Affect}

How then do these interlinked factors work? Contra Campbell, for example, who argues that "there is nothing outside of discourse" (Campbell, 1998: 4), we suggest that September $11^{\text {th }}$ provides us with an interesting empirical case study precisely because of those initial moments after 9/11 in which witnesses gasped, but could not find the words to articulate their feelings (Holland, 2009; Morris, 2004; Troyer, 2001), hint at an important avenue of enquiry, which has been made apparent by the work of scientist colleagues (Damasio 1999).

A purely discursive analysis risks veiling a crucial component of the meaningmaking process: biocultural affect. The process of framing events to enable and encourage understanding does not begin with foreign policy speeches; it begins as soon as an event is witnessed and prior to conscious awareness of it. As William Connolly (2002), Gerard Toal (2003), Antonio Damasio (1999) and John Protevi (2009) argue, this process is essential in everyday life. Affect helps to ensure that the infinite complexity of experience is reduced and potential 
responses to events are rendered comprehensible to the individual, rather than appearing as a potentially endless rational-choice marathon of the weighing of possibilities. Without this non-conscious shortcut the most inane questions and options could be pondered and deliberated indefinitely and potentially without conclusion. In this sense, rationality/cognition and affect are mutually implicated, rather than affective responses constituting 'deviations' from cognition. Cognition is, in other words, 'both affective and cognitive, with ... an emphasis to be placed on the unconscious affective evaluations that precede' rational calculations (Protevi 2009, 25).

Connolly's work has been central to the project of understanding the complex relationship of affective experience to discursive construction. He has been at the forefront of attempts to theorise the relationship of affect, thinking and language, through an appreciation of the interpenetration of biology and culture (Connolly 2002, 2005). Connolly's project has attempted to break down engrained distinctions between nature and culture in favour of interacting layers of biocultural complexity' (Krause, 2006). And, this complexity has been increasingly recognised in understandings of foreign policy and international relations with recent research taking seriously the role played by 'emotions' yet without fully developing the 'zone of indiscernability' between biology and culture that is often at the root of reactions to traumatic events such as $9 / 11$.

For Connolly, the part of the brain and body that enacts affect forms a series of loops and counterloops that interact with the rest of the body and with the larger culture (Connolly, 2002: 75; see also Thrift 2008). Connolly's project very 
directly breaks down the nature/culture distinction in favour of a bioculturally layered conception of thought. It is in the 'middle range of complexity' between nature and culture that we reach a 'zone of indiscernability' in which neither category of 'nature' or 'culture' stands on its own (as traditionally envisioned). This zone requires and indeed demands 'much more attention today in cultural theory' (Ibid.: 63-64). As he argues, a 'multilayered conception of culture and thinking is needed... that comes to terms with how biology is mixed... into every layer of human culture' (Ibid.: 62). Material factors such as the body and bodily reactions are not "outside" of culture, but rather come to be caught up in its multiple layering. For Connolly, the "brain network must both engage the linguistically mediated world and respond to multiple signals from the body that bear traces of past experiences upon them" (Ibid.). It is out of this nebulous area of intermixing of biology and culture that more conscious thoughts, reactions, and representations spring.

Connolly's project then works in two complementary directions: against social science blinkered by Enlightenment rationality, through a realisation of the importance of affect to political life; and against the linearity and causality of misappropriated natural determinism, through a realisation of the layering of the cultural in the biological. Importantly, in exploring this complex relationship between affect and discourse, Connolly argues that this should not cause concern amongst those who rightly focus on the constitutive role of discourse in politics.

Does attention to the role of affect in the mobility of thought denigrate the role of language? Not at all. First, linguistic distinctions, in the largest sense of that idea, are differentially mixed into affective states at each 
level of complexity, even if they do not exhaust them and even if many thoughts move too fast to render the linguistic element explicit. Affect would be more brutish than it is without language (Ibid.: 73).

Thus not only is language bound up with affect, but it is also a social medium through which affect is expressed into more defined linguistic categories which imperfectly express the affective reaction experienced.

Drawing upon these insights, a biocultural reading of September $11^{\text {th }}$ shows us how affective experience of events can vary geographically and culturally. Worldwide, there were a multiplicity of responses to the events of September $11^{\text {th }}$ and the related diversity of subsequent constructions. Kleinfeld (2003) has hinted for example that '9/11' was experienced very differently in Sri Lanka, due to a distinct cultural context, replete with more commonplace understandings of political violence. Similarly, Holland (2012) argues that Tony Blair's emphasis on the scale of the loss of life, rather than experiencing or expressing shock at the events themselves, can be understood with reference to the unique British cultural context. Likewise, in Australia there is evidence to suggest that September $11^{\text {th }}$, whilst still shocking, was understood in very different temporal terms to the perception of absolute temporal rupture that characterised the dominant American experience (Holland, 2010, 2013). Although clearly not homogenous, the pervasiveness of American security culture facilitated a prevalent affective experience of September $11^{\text {th }}$ in the United States, which is demonstrated by a considerable weight of empirical evidence. This prevalent experience was informed by a relatively widespread and consistent biocultural layering. 
Drawing upon Connolly, and building on the work of IR affect scholars, the key claim made here is that the affective responses American citizens articulated in September $11^{\text {th's }}$ immediate aftermath attempted to put into words the visceral affect that the experience of the events initiated (Ross, 2006; Saurette, 2006; Solomon, 2012). This biological affect took place before the words of the Bush government began to harmonise understandings of ' $9 / 11$ ' around increasingly hegemonic framings. However, these biological reactions - of shock and horror were inevitably conditioned by the cultural context in which American citizens had learned to expect the everyday.

\section{Conditioning Context: American Security Culture}

Take, for instance, one interviewee's frank admittance that they 'felt nothing', because they 'couldn't understand' (Sato, 2001). To understand how this was possible, it is necessary to revisit the conditioning context of 1990s America, which shaped American expectations of the everyday. The cultural context of unipolarity in 1990s America, characterised by self-proclaimed indispensability and an American-inspired 'end of history', conditioned the prevalent affective experience of September 11 th (Albright, 1998; Fukuyama, 1992). Culture and biology mattered, and it was through their interweaving that the affective experience of September $11^{\text {th }}$ was characterised. For instance, as one American citizen noted after ' $9 / 11$ ', the events had 'to be set off against what one has been conditioned to' (Fan, 2001). Their fellow American's frank admittance that they 'felt nothing', because they 'couldn't understand' (Ibid.), is a logical, even likely, affective response, given the cultural context in which Americans had learned to 
expect the everyday. Indeed, such a response likely indicates the sheer contrast with the everyday expectations produced by American security culture and their encounter with the events of 9/11 (see Butler 2004).

A particular security culture, which located danger and violence almost exclusively outside of America (Campbell, 1998), helped to initially place the events of September $11^{\text {th }}$ beyond comprehension for many watching Americans. Dealing with foreign policy generally, and the case study of ' $9 / 11$ ' specifically, it is useful to speak of a predominant American security culture, which helped to structure the prevalent affective American response to the events. A security culture is a shared body of assumptions, belief and norms, as well as associated practices, related to the security of the state and/or other social actors (Katzenstein, 1996). Security cultures are thus 'patterns of thought and argumentation that establish pervasive and durable security preferences by formulating concepts of the role, legitimacy and efficacy of particular approaches to protecting values. Through a process of socialisation, security cultures help establish the core assumptions, beliefs and values of decision-makers' and the general public about 'how security challenges can and should be dealt with' and, more fundamentally, about what is a security challenge or what is likely to become one. This definition helps to specify what we mean by 'culture' in this instance, and how culture conditioned the experience of the events of September 11th 2001 (Williams, 2007: 279).

In the United States understandings of security have long been conditioned by cultural beliefs in the myths and narratives of American exceptionalism. 
McCrisken argues that American exceptionalism centres on the belief that the United States is unique and superior (McCrisken, 2003). It serves as the basis for a cultural identity, in accordance with which foreign policy is developed (Katzenstein, 1996). The origins of exceptionalism lay in the self-understanding of early settlers in the New World. Thomas Paine remarked that 'we have it in our power to begin the world over again' precisely because, as Thomas Jefferson noted, America is 'kindly separated by nature and a wide ocean from the exterminating havoc of one quarter of the globe; too high-minded to endure the degradations of others' (Jefferson, 1801). As Gaddis has argued, it is this physical isolation and the security afforded by two vast oceans that enabled Americans to reach the zenith of perceived invulnerability in the late 1990s (Gaddis, 2004). A notable portion of cultural commentary on US foreign relations during the 1990s centered on such notions. Commentators on both the left and right styled the 1990s as a "holiday from history" and contended that 9/11 awoke Americans from "a frivolous if not decadent decade-long dream, even as it dumps us into an uncertain future we never bargained for" (Will and Rich, cited in Chollet and Goldgeier, 2008: xi). As Chollet and Goldgeier (2008: 316) argue, the "end of the Cold War made many Americans and their leaders believe the world had become more benign, and therefore, of less concern". It was this perceived and felt invulnerability of the 1990s against which affective reactions and their subsequent discursive articulation of September $11^{\text {th }}$ should be understood.

Building on Experience: Affective Responses and Constructing a Resonant Discourse It was this cultural context and the security myths of the late 1990s that conditioned the prevalent American experience of the events of September $11^{\text {th }}$. 
Particular affective responses preceded the Bush Administration's construction of ' $9 / 11^{\prime}$ which discursively accounted for them. Drawing on interviews conducted in the weeks after 9/11 (13 September - 1 November 2001), our empirical analysis captures this process of discursive capture, personal emotional realignment, and affective investment. Accounting for affect and sculpting a narrative that incorporated the visceral experience of September $11^{\text {th }}$ was central to the Bush Administration's attempts to craft a resonant framing of '9/11'. Here, we recount four useful examples, which indicate the embedding of the Bush Administration's official discourse within the post 9/11 biocultural landscape. In turn, these examples are: the perceived foreign-ness of the events; the understanding that the events represent a moment of temporal rupture; the notion that the events were beyond understanding; and the idea that a 'way of life' had come under threat. In each instance, plugging into and accounting for the prevalent affective experience of September 11th helped to ensure the cultural and public resonance of official constructions (see Solomon, 2012).

\section{(i) $9 / 11$ as Foreign}

The first useful example of 'accounting for affect' and 'building on experience' is found in the perceived 'foreign-ness' of the events of September $11^{\text {th }}$. On September $11^{\text {th }}$, the discrepancy between biocultural expectation and apparent reality ensured that the foreign-ness of the events was 'felt' before it was put into words; the images Americans faced were seen to not belong, and were met with corresponding disbelief and denial. 
In August of 2001, Americans were quite accustomed to seeing images of chaos, violence and terrorism elsewhere. Generally, Americans understood that largescale (illegitimate) violence was something that happened 'out there', in the rest of the world, but not 'here', not 'at home'. American security culture located the dangers of an anarchical international system beyond both the contemporary American era and the physical distance of the world's two largest oceans (Gaddis, 2004). These cultural understandings of violence and space meant that the events of September $11^{\text {th }}$ were met with corresponding spatial distanciation. Events were viewed as likely 'news from some other country' (Castello, 2001).

For Croft, on September 11 $11^{\text {th }} 2001$, 'the violence outside ... spilled over into the American inside' (Croft, 2006: 37). While violence may be 'so much an everyday event for so much of the world', it was unusual in the American Homeland and was correspondingly viewed as being sourced from beyond America's borders, in the kind of places where violence belonged more naturally (Ibid.). What shocked viewers was not the images of violence in and of themselves, but that (slowly) they had to reconcile these images with the knowledge that the events were not taking place elsewhere, but rather were unfolding in America. This difficulty in reconciling the proximal location with the scale of violence fostered much of the incomprehension that characterised the initial reactions of many watching Americans.

“I can't believe it ... it's happening here, in the US. You see these things out there, but not here in your own country" (Senor, 2001).

“I'm still in a state of shock; I don't believe this could happen on American soil" (Farley, 2001). 
Occurring in America made the events hard to comprehend. The familiarity of the New York skyline and the World Trade Center buildings juxtaposed the unfamiliarity of witnessing violence 'at home'. ${ }^{2}$ The foreign-ness of the events was experienced before the process of naming and locating an external enemy had taken place (e.g. Ross, 2006). Slowly, as the official narration and naming took hold and, amplified by media punditry, the meaning of the events slowly harmonised around Bush's clarion calls, the same questions started to appear. Foremost amongst these questions was, 'why do they hate us?' Ground Zero came to represent the point at which the violence and fanaticism of the outside had somehow permeated the usually secure borders of the American inside: the point at which external hatred tore at the heart of a loving America. That the very worst' in the world were seen to have struck a blow against 'the very best' relied, of course, on the particular framing of the events put forward by the Bush Administration and a particular security culture centred around American exceptionalism (e.g. Bush, 2001). While foreign-ness was 'felt' before it was articulated, the official narration of ' $9 / 11$ ' accounted for the 'feeling' that events did not belong, juxtaposing them with a naturalised patriotism. Binaries of love and hate, inside and outside, America and Afghanistan, good and evil, us and them, were central to the official construction of ' $9 / 11^{\prime}$ and built upon the affective experience of September $11^{\text {th }}$ as a foreign, external and wholly 'Other' event.

(ii) 9/11 as Temporal Rupture

\footnotetext{
2 Of course, this 'unfamiliarity' relied upon particular discursive constructions of violence.
} 
Parallel to the difficult realisation that events were occurring in the United States came the struggle to accept that something like this could occur in the present era. As one witness recalled, experiencing temporal distanciation, it was like watching 'something in history' (Waters, 2001). What seemed immediately clear to viewers was that something had changed and what had gone before was unlikely to ever be fully restored. This transition was felt at a fundamental level. Witnesses and interviewees immediately spoke of an era of invulnerability and American exceptionalism in the past tense (Grayson, 2001). And they acknowledged that, going forward, the innocence, naivety and safety of that era was unlikely to return. 'Just as susceptible to mass devastation as any other part of the world', Americans watched the events of September 11th 2001 with the realisation that they 'were no longer chosen people' (Anderson, 2001). Before the articulation of the terrorist threat and harbouring states was undertaken by the Bush Administration - before Americans were told what would come next they were already aware that what they had before was now gone. Temporal rupture was experienced before it was articulated. It was experienced as the dusk of a blissful era and articulated as the dawn of new and dangerous times (Bush, 2001; Hay, 1996). The political effect of this articulation was to demand and legitimise new and unprecedented policy options in response.

(iii) $9 / 11$ as Beyond Understanding

A third useful example of the relationship between experience and construction, as well as the resonance that a cogent relationship can generate, is found in the notion that ' $9 / 11$ ' was beyond understanding. The incomprehensibility that characterised the experience of September $11^{\text {th }}$ for many Americans was artfully 
reworked into inexplicability in the official construction of ' $9 / 11$ '. Whilst crucially distinct, this framing was projected back onto the experience of September $11^{\text {th }}$ to seamlessly explain and account for biocultural feelings of incomprehension. Culturally informed incomprehension was replaced with a politically efficacious inexplicability, which transformed September $11^{\text {th }}$ from a series of events beyond understanding into ' $9 / 11$ ': a series of events that cannot be justified or explained.

Consider, again, the example of one interviewee claiming that they 'felt nothing' because they 'couldn't understand' (Sato, 2001). Official constructions accounted for the prevalent experience of September $11^{\text {th }}$ as beyond understanding, by providing Americans with a ready-made reason explaining, justifying and validating their inability to comprehend: the actions of terrorists are motivated by a pure and perverse evil beyond the realm of comprehension for ordinary, loving Americans and beyond justification in a modern, loving United States. In both the biocultural experience and discursive construction, September $11^{\text {th }}$ and '9/11' cannot be understood, but in the former the reason for this lies in the exceptionality and foreign-ness of the events themselves, whereas in the latter the reason lays in the motivations of terrorists. This particular element of official narratives of ' $9 / 11$ ' was resonant as it accounted for, explained and verified an affective response that struggled to understand and rationalise the events. It was politically effective as feelings of the events as 'beyond understanding' in experiences of September $11^{\text {th }}$ were shifted to focus on the construction of an enemy in dominant narratives of ' $9 / 11$ '. Official constructions of the enemy as 
beyond understanding - as pure evil - helped to render particular policy responses natural, whilst others unthinkable.

(iv) 9/11 as Attack on a 'Way of Life'

A fourth useful example of this process of embedding official constructions of ' $9 / 11^{\prime}$ in the affective biocultural experience of September $11^{\text {th }}$ is found in appeals to 'ways of life'. Official narratives that spoke of an attack on a way of life may have sounded odd or even meaningless to non-American ears, but in a nation that experienced a profound sense of trauma, as life ceased to operate along the lines cultural expectations demanded (Edkins 2003), such narratives helped to fill the awkward and uneasy void in meaning generated by September 11'th (Campbell, 2001; Holland, 2009; Nabers, 2009). For many Americans, on September $11^{\text {th }}$ the certainties of American security culture were seen to no longer hold true; cultural expectations about how the world should work and America's place in that world were invalidated. Appealing to the notion of an attack on a way of life, the Bush administration acknowledged this biocultural experience of the failure of the everyday. Again, official constructions of ' $9 / 11$ ' resonated as they accounted for and explained prominent experiences of the events of September $11^{\text {th }}$. And, again, they posed important political implications as appeals to a 'way of life' served to naturalise its defence overseas.

As with appeals to a 'way of life' and notions of ' $9 / 11$ ' as 'beyond understanding', it is in the relationship between the experience of September $11^{\text {th }}$ and the construction of ' $9 / 11$ ' that we can begin to understand the intensity of attempts to defend dominant official constructions of ' $9 / 11$ ' in the decade since. 
Biocultural experience was actively incorporated into official constructions. It was more than the influence of the presidential 'bully pulpit' that facilitated resonance. Rather, as Americans bought into a discourse that readily accounted for the affective experience of $9 / 11$ - an often traumatic and uneasy void of meaning - they became particularly invested in the official narration offered by the Bush Administration (and which subsequently rippled throughout American society and culture). The resonance and endurance of this production was aided by its ability to account for, articulate and explain the initial affective experience of September $11^{\text {th }}$ for many Americans. And, this framing posed important political ramifications in enabling, shaping and constraining the official response to the events.

\section{The Politics of Affect: Resonance and Affective Investment}

The affective experience of $9 / 11$ for individual citizens was enabled by a mixture of biology and widespread American security culture that formed a background against which events would be experienced and assessed, before conscious thought and categorisation took place. Instantaneous 'understandings' - of shock; of the events not belonging; of 'feeling' the events as a moment of rupture; and of them invalidating the predictable normality of a usual way of life - were all part of the affective experience of September $11^{\text {th }}$ conditioned by American security culture. The Bush Administration adeptly incorporated these experiences within official constructions such that Americans became affectively invested within them. Moreover, these constructions accounted for affective experiences and plugged back into the broader cultural context thus facilitating its embeddedness within American society (Croft, 2006; Jackson, 2005). By 
accounting for affect and plugging into the cultural context, the war on terror discourse produced a resonant official construction of 9/11, with which it was difficult to argue (Krebs and Lobasz, 2007). In each type of affective experience, the discourse helped to account for it, and sculpted it, through its inclusion into a particular yet contingent and contestable narrative. It was not obvious that an affective experience of $9 / 11$ as 'foreign', as a temporal rupture, or as incomprehensible should lead naturally into a policy of intervention abroad. Why was $9 / 11$ not understood as a criminal act or crime against humanity thereby making more thinkable policy options of isolation, diplomacy or greater development aid, given the varying foreign policy traditions with the US?. These constructions served a key political function to render a contingent and contestable policy response as natural, logical, imperative and even unavoidable. More than simply discursive construction, affect - more than the mere articulation of words themselves - was central to the resonance of such enabling constructions.

In this sense, this approach to biocultural affect, discourse, and emotion extends beyond a number of state-level analyses of emotions in IR. In doing so, it helps to more vividly draw attention to the politics of the affect-emotion relationship. For instance, take Löwenheim and Heimann's (2008) insightful study on revenge in international politics. They rightly argue that revenge is an emotional dynamic that contributes to specific political outcomes, and develop a theory of how states may experience revenge. As they argue, “corporate actors can experience emotions through the individuals that compose them, identify with them, and are constituted by them". Leaders, acting as state agents, "possess emotions that are 
distinct from their personal emotions because of their institutional capacity and embeddedness" (Ibid.: 690). From another angle, Hall develops a state-level theory of diplomatic displays of anger. For him, "state actors - ranging from top leaders, policymakers, officials, and diplomats, to low-ranking soldiers - can collectively project an image of anger through their discourse, symbolic gestures, and concrete actions" (Hall, 2011: 532). Sasley critiques yet builds upon these approaches to develop an understanding of state-level emotions by drawing upon intergroup emotions theory. For Sasley (2011: 453-454), better theorizing how states' may experience emotion - and thereby gaining new analytic leverage over the field's traditional unit of analysis - may lead to increased acceptance of emotions research in IR. As he argues, focusing on the state as a monolithic actor does not account for the variety of emotional responses within a state, and focusing on individual leaders as representatives of the state, while useful, may be too specific to develop generalizable theories of emotion. While each of these studies rigorously theorize (in different ways) the various relationships between states and emotions, their focus nevertheless downplays the capacities of elitelevel discourses to channel (without of course "controlling") affective responses into particular emotional directions. And while we follow Sasley's theorizing states not as black boxes but as social groups that experience emotions, our work analyzes the prior ontological step of moving from initial biocultural affective reactions to events to the more defined emotional responses that Sasley rightly conceptualizes. Such intra-state processes of biocultural affective dynamics are constitutive in producing and sustaining widespread understandings of political contexts themselves - the often indistinct affective contexts out of which more defined emotions are articulated. Examining not just elite discourses but how 
such discourses resonate with mass-level feelings and affective reactions to events promises to enhance our understanding of both the efficacy of political discourses and how everyday-level affects can become transformed into politically consequential emotional effects.

The crux of our argument lies in the process of naming affect as emotion. Influence over the discursive conditions of emergence, for affect to be named as emotion, often lies in the hands of states. As happened after September 11 th, citizens are told what they experienced. Americans were told that their experience of September $11^{\text {th }}$ as 'foreign' could be understood as the emotion of 'anger' that naturally followed an act of war declared by an external enemy. They were told that the experience of 'rupture' and change could be understood through the knowledge that America had now entered an era of war. They were told that incomprehension could be explained by the fact that events were inexplicable. And, they were told that experiencing the events as totally out-ofthe-ordinary was in keeping with terrorist desires to attack our 'way of life'. The affective experience of September $11^{\text {th }}$ - which centred on themes such as numbness, confusion, a lack, and rupture - was named, through official discourse, around emotions such as anger, sadness, sorrow, love and patriotism. This capacity to account for affect and build upon experience should be incorporated into constructivist and discourse analytic works attempting to both theoretically understand and empirically account for the political possibility of foreign policy, such as the response to $9 / 11$.

\section{Conclusion}


The main contribution that this paper offers is that foreign policy, whilst discursive and culturally embedded, also must affectively resonate to be perceived as legitimate (Holland 2013). Foreign policy is bioculturally embedded. Moreover, the political possibility of foreign policy, particularly following traumatic events, is partially determined by its construction in terms that account for the biocultural landscape such events are seen and felt to carve out. If there is a disconnect between official foreign policy discourse and the prevalent affect experience of citizens - if they are 'felt' and perceived to be incommensurate - it is likely to be difficult to realise or sustain foreign policy in the short, medium or long term. Take, for instance, a hypothetical situation in which the Bush Administration opted to ignore the predominant affective experience of Americans and chose instead to articulate a foreign policy that emphasised the continued invulnerability of Americans. Such an articulation would likely have failed to garner significant public support - and certainly would not have cultivated significant affective investment - despite that, in actual fact, Americans did and do remain a people who are safer from foreign threat than nearly any other (see Mueller, 2006).

Our argument then is that, as well as being discursive and culturally embedded, the political possibility of foreign policy is partially determined in its ability to affectively invest its audience within it. Affect matters: it influences foreign policy discourse, mass responses to it, and helps to constitute collective understandings of what foreign policy problems "are" as well as sustaining those understandings at a visceral level. Often, however, as was the case after September $11^{\text {th }}$, states retain a quite influential position in their ability to 
articulate affect as emotion - to name that which citizens 'felt'. This is certainly not always the case, and many important examples exist of states failing to articulate their preferred policies to resonate affectively, and where NGOs 'shame' states to pursue a political agenda that they likely would not have pursued otherwise (Franklin, 2008). Frequently though, as was the case after 9/11 and as tends to follow perceived 'crisis situations', affect is often what states make of it. It is this ability to account for affect that helps to ensure resonance and enable policy.

Taking a step back, it is worth remembering that unpicking the fabric of ' $9 / 11^{\prime}$ is crucial to realising its fabricated nature. And this is a task at which International Relations has excelled in recent years (e.g. Jackson, 2005). Similarly, recognising the resonance and enduring dominance of particular readings of ' $9 / 11$ ' rely, in turn, on recognising that this fabrication has woven within it the affective experience of September $11^{\text {th }}$. There has been a tendency for analysis to focus on the elite-level framings of the Bush administration at the expense of processes of meaning production in the general populace. To isolate the two is to limit understandings of either, given the intimate relationship between them. A decade on from ' $9 / 11$ ', it is vital to reconnect these levels of meaning making. Taking seriously the experience of the events for 'normal' Americans helps us to understand the resonance and longevity of dominant narrations, as well as their subsequent defence. Analytically, it is important to reconnect the experience of September $11^{\text {th }}$ for ordinary Americans with official framings; it is important to recognise the (bio)culturally embedded nature of official policy discourse. And, normatively, once recognised, it is imperative to unpick the seams that have so 
effectively stitched together via affect and contingent construction. After September $11^{\text {th }}$, as the Bush Administration retained substantial influence of the (re)production of dominant discourses, affect was what the state made of it. Such recognition, it is hoped, might be a useful starting point to contest and resist dominant framings of ' $9 / 11$ ', the 'War on Terror' and within other interventionist discourses in future research. 


\section{Bibliography}

Albright M (1998) Interview on NBC-TV "The Today Show" with Matt Lauer, Columbus, Ohio, February 19, 1998.

Anderson L (2001) 'Witness and Response', Library of Congress, SR375, 13 Sept 2001.

Balzacq, T (2005) Three Faces of Securitization: Political Agency, Audience, and Context. European Journal of International Relations 11(2): 171-201.

Barnett, M. (1999) Culture, Strategy, and Foreign Policy Change: Israel's Road to Oslo. European Journal of International Relations 5(1): 5-36.

Bleiker R and Hutchison E (2008) Fear no more: emotions in world politics. Review of International Studies 34(1): 115-135.

Bush, GW (2001) Address to Joint Session of Congress and the American People, 20 September 2001.

Butler, J (2004) Precarious Life: The Powers of Mourning and Violence. London and New York: Verso.

Campbell D (2001) Time is Broken: The Return of the Past in the Response to September 11, Theory and Event, 5(4).

Campbell, D. (1998) Writing Security: United States Foreign Policy and the Politics of Identity, Revised Edition, Minnesota: University of Minnesota Press.

Castello V (2001) 'Witness and Response', Library of Congress, SR321, 19 October 2001.

Chollet D and Goldgeier J (2008) America Between the Wars, New York: Public Affairs.

Connolly W (2002) Neuropolitics: Thinking, Culture, Speed, Minnesota: University of Minnesota Press. 
Connolly W (2005) The Evangelical, Capitalist Resonance Machine, Political Theory, 33(6): 869-886.

Crawford, N (2000) The Passion of World Politics: Propositions on Emotions and Emotional Relationships. International Security 24(4): 116-156.

Croft S (2006) Culture, Crisis and America's War on Terror, Cambridge: Cambridge University Press.

Damasio A (1999) The Feeling of What Happens: Body and Emotion in the Making of Consciousness, New York: Harcourt.

Doty R (1993) Foreign Policy as Social Construction: A Post-Positivist Analysis of U.S. Counterinsurgency Policy in the Philippines, International Studies Quarterly, 37(3): 297-320.

Edkins J (2003) Trauma and the Memory of Politics, Cambridge: Cambridge University Press, 2003.

Fan J (2001) 'Witness and Response' (SR247), October 18, 2001.

Farley (2001) 'Witness and Response', Library of Congress, 2001.

Franklin J (2008) Shame on You: The Impact of Human Rights Criticism on Political Repression in Latin America. International Studies Quarterly 52(1): 187-211.

Fukuyama F (1992) The End of History and The Last Man, London: Macmillan.

Gaddis JL (2004) Surprise, Security, and the American Experience, London: Harvard University Press.

Grayson M (2001) 'Witness and Response', Library of Congress, SR327, 1 Nov 2001. Hall T (2011) We Will Not Swallow This Bitter Fruit: Theorizing a Diplomacy of Anger, Security Studies 20(4): 521-555.

Hansen L (2006) Security as Practice: Discourse Analysis and the Bosnian War, Abingdon: Routledge. 
Hansen L (2011) Theorizing the Image for Security Studies: Visual securitization and the Muhammad Cartoon Crisis. European Journal of International Relations 17(1): 51-74.

Hay C (1996) Narrating Crisis: The Discursive Construction of the 'Winter of Discontent', Sociology, 3(2): 253-277.

Holland J (2009) From September $11^{\text {th }} 2001$ to 9/11: From Void to Crisis. International Political Sociology, 3(3): 275-292.

Holland J (2010) Howard's War on Terror: A Conceivable, Communicable and Coercive Foreign Policy Discourse, Australian Journal of Political Science, 45(4): 643-661.

Holland J (2012) Blair's 'War on Terror': Selling Intervention to Middle England, British Journal of Politics and International Relations, 14(1): 74-95.

Holland J (2013) Selling the War on Terror: Foreign Policy Discourses after 9/11, London and New York: Routledge.

Holland J and Jarvis L (forthcoming) "Night Fell on a Different World": Experiencing, Constructing and Remembering 9/11.

Hutchison E (2010) Trauma and the Politics of Emotions: Constituting Identity, Security, and Community after the Bali Bombing. International Relations 24(1), $65-86$.

Jackson R (2005) Writing the War on Terrorism: Language, Politics, and Counterterrorism. Manchester and New York: Manchester University Press. Jefferson T (1801) 'First Inaugural Address', Washington D.C. Katzenstein P (ed) (1996) The Culture of National Security, New York: Columbia University Press. 
Kleinfeld M (2003) Strategic Torping in Sri Lanka: September $11^{\text {th }}$ and the Consolidation of Political Position, Geopolitics, 8(3): 105-126.

Krause S (2006) Brains, Citizens, and Democracy's New Nobility, Theory and Event, $9(1)$

Krebs R and Lobasz J (2007) Fixing the Meaning of 9/11: Hegemony, Coercion, and the Road to War in Iraq, Security Studies, 16(3): 409-451.

Lapid Y and Kratochwil F (eds) (1995) The Return of Culture and Identity in IR Theory. Boulder: Lynne Rienner.

Lebow R (2009) A Cultural Theory of International Relations. Cambridge: Cambridge University Press.

Löwenheim O and Heimann, G (2008) Revenge in International Politics, Security Studies, 17(4): 685-724.

Massumi B (2007) Potential Politics and the Primacy of Preemtion, Theory and Event, $10(2)$

McCrisken T (2003) American Exceptionalism and the Legacy of Vietnam, London: Barnes and Noble.

Mercer J (2010) Emotional Beliefs, International Organization 64(1): 1-31.

Millennium (2013) special issue on 'Materialism in World Politics,' 41(3).

Milliken J (1999) The Study of Discourse in International Relations. European Journal of International Relations 5(2): 225-254.

Morris R (2004) Images of Untranslatability in the US War on Terror, Interventions: International Journal of Postcolonial Studies, 6(3): 401-423.

Mueller J (2006) Overblown: How Politicians and the Terror Industry Inflate National Security Threats, and Why We Believe Them. New York: Free Press. 
Nabers D (2009) Filling the void of meaning: Identity construction in U.S. foreign policy after September 11, Foreign Policy Analysis, 5(2): 191-214.

Protevi, J (2009) Political Affect: Connecting the Social and the Somatic. Minneapolis and London: University of Minnesota Press.

Protevi, J (2010) Rythhm and Cadence, Frenzy and March: Music and the geo-biotechno-affective assemblages of ancient warfare. Theory \& Event 13(3).

Ronald L, Jepperson L, Wendt A, and Katzenstein P, (1996) Norms, Identity, and Culture in National Security, in Katzenstein P (ed) The Culture of National Security: Norms and Identity in World Politics (New York: Columbia University Press).

Ross A (2006) Coming in from the Cold: Constructivism and Emotions. European Journal of International Relations 12(2): 197-222.

Ross A (2014) Mixed Emotions: Beyond Fear and Hatred in International Conflict. Chicago: University of Chicago Press.

Sasley B (2010) Affective attachments and foreign policy: Israel and the 1993 Oslo Accords. European Journal of International Relations 16(4): 687-709.

Sasley B (2011) Theorizing States' Emotions, International Studies Review, 13:3 (2011): 452-476.

Sato K (2001) 'Witness and Response', Library of Congress, SR247, 16 Oct 2001. Saurette P (2006) 'You dissin' me?': Humilation and Post 9/11 Global Politics, Review of International Studies, 32(3): 495-522.

Senor J (2001) 'Witness and Response’, Library of Congress, SR015, 11 October 2001.

Shouse E (2005) Feeling, Emotion, Affect, Media and Culture Journal, 8(5), available online at http://journal.media-culture.org.au/0512/03-shouse.php. 
Silberstein S (2002) War of Words: Language, Politics, and 9/11. London: Routledge.

Solomon T (2012) 'I wasn't angry, because I couldn't believe it was happening':

Affect and discourse in responses to 9/11, Review of International Studies, 38(4): 907-928.

Thrift N (2008) Non-Representational Theory: Space, Politics, Affect. London:

Routledge.

Toal G (2003) 'Just out Looking for a Fight': American Affect and the Invasion of Iraq, Antipode, 35(5): 856-870.

Troyer, J (2001) Language Fails America in Struggle to Understand. The Minnesota Daily.

Waters N (2001) 'Witness and Response', Library of Congress, SR025, 27 October 2001.

Weldes J, Laffey M, Gusterson H, and Duvall R, (1999) Introduction: Constructing Insecurity, in Weldes J, Laffey M, Gusterson H, and Duvall R, (eds) Cultures of Insecurity. Minneapolis: University of Minnesota Press.

Williams M (2007) Culture and Security: Symbolic Power and the Politics of International Security. London and New York: Routledge.

Williams P (2007) From Non-intervention to Non-indifference: the Origins and Development of the African Union's Security Culture, African Affairs, 106(42): 253-279.

Williams R (1983) Keywords, Oxford: Oxford University Press. 